KONSTRUKTIVISME, Vol. 10, No. 1, Januari 2018

p-ISSN: 1979-9438; e-ISSN: 2442-2355

FKIP Universitas Islam Balitar, Blitar

Http://konstruktivisme.unisbablitar.ejournal.web.id; Email: konunisba@gmail.com

\title{
PENERAPAN MODEL PEMBELAJARAN COOPERATIVE INTEGRATED READING AND COMPOSITION (CIRC) DIPADU PROBLEM BASED LEARNING (PBL) UNTUK MENINGKATKAN KEMAMPUAN MEMECAHKAN MASALAH DAN KEMAMPUAN BERPIKIR KRITIS MAHASISWA SEMESTER V TAHUN AKADEMIK 2016/2017 UNIVERSITAS ISLAM BALITAR
}

\author{
Eva Nurul Malahayati \\ Prodi Pendidikan Biologi FKIP Universitas Islam Balitar Blitar \\ Jl. Majapahit No. 12A Blitar \\ E-mail : eva.malahayati@yahoo.co.id
}

\begin{abstract}
ABSTRAK :
Penelitian ini bertujuan untuk meningkatkan kemampuan memecahkan masalah dan berpikir kritis dengan penerapan model pembelajaran Cooperative Integrated Reading And Composition (CIRC) dipadu ProblemBased Learning ( $\mathrm{PBL}$ ) pada mahasiswa semester V tahun akademik 2016/2017 Universitas Islam Balitar, Blitar. Subjek penelitian ini adalah mahasiswa peserta mata kuliah Strategi Belajar Mengajar yang berjumlah 24 mahasiswa. Hasil penelitian menunjukkan bahwa prosentase kemampuan memecahkan masalah terjadi peningkatan sebesar $19,48 \%$ dari siklus I ke siklus II setelah penerapan model pembelajaran CIRC dipadu dengan PBL. Sedangkan penerapan model pembelajaran CIRC dipadu dengan PBLdapat meningkatkan kemampuan berpikir kritis dapat meningkatnya nilai rata-rata prosentase kemampuan berpikir kritis berdasarkan LKM terjadi peningkatan sebesar $29,80 \%$ dari siklus I ke siklus II dan kemampuan berpikir kritis berdasarkan nilai postes pada siklus I dan siklus II berturut-turut $57 \%$ dan $71 \%$, sehingga dapat dikatakan terjadi peningkatan sebesar $24 \%$ dari siklus I ke siklus II. Berdasarkan paparan hasil tersebut dapat disimpulkan bahwa penerapan pembelajaran CIRC dipadu dengan PBLpada mahasiswasemester V tahun akademik 2016/ 2017 Matakuliah SBM Universitas Islam Balitar dapat meningkatkan kemampuan memecahkan masalah dan berpikir kritis.
\end{abstract}


Eva Nurul Malahayati. 2018. Penerapan Model Pembelajaran Cooperative Integrated

Reading Dipadu Problembased Learning (PBL) Untuk Meningkatkan Kemampuan

Memecahkan Masalah dan Kemampuan Berpikir Kritis Mahasiswa Semester V Tahun Akademik 2016/2017 Universitas Islam Balitar

Konstruktivisme, 10 (1): 35-48

Kata kunci: model pembelajaran cooperative integrated reading and composition (CIRC), model problem based learning (PBL), kemampuan memecahkan masalah, kemampuan berpikir kritis.

ABSTRACT:

The purpose of this research was to increase the problem solving and critical thinking skills with the implementation of learning model Cooperative Integrated Reading and Composition (CIRC) combined Problem Based Learning (PBL) of the students in the fifth semester at Islamic University of Balitar, Blitar in the 2016/2017 Academic Year. The subject of this research were 24 students of teaching and learning strategy course. The result of this research showed that percentage problem solving skills was improved of $19,48 \%$ from cycle I to cycle II after implementation learning CIRC combined PBL learning. While the implementation of CIRC combined PBL learning can increased the ability of critical thinking also increased the average percentage of critical thinking based on LKM of $29,80 \%$ from cycle I to cycle II and the critical thinking skill based on the post-test value and cycle I and cycle II respectively were $57 \%$ and $71 \%$, so it can be said that there were increased of $24 \%$ from cycle I to cycle II. Based on explanation of the results, it can be concluded that the implementation of CIRC combined PBL for students in the fifth semester at Islamic University of Balitar in the 2016/2017 Academic Year in SBM course can increased the problem solving and critical thinking skills.

Keywords: Cooperative Integrated Reading and Composition (CIRC) Learning Model, Problem Based Learning (PBL) Learning Model,Problem Solving Skill, Critical Thinking Skill.

\section{PENDAHULUAN}

Kurikulum dan proses pembelajaran memiliki peranan penting dalam mewujudkan tujuan pendidikan nasional. Hal ini dapat dilihat dari semakin berkembangnya kurikulum yang digunakan untuk penyempurna kurikulum sebelumnya.Perubahan kurikulum ini dipengaruhi oleh perubahan paradigma 
Eva Nurul Malahayati. 2018. Penerapan Model Pembelajaran Cooperative Integrated

Reading Dipadu Problembased Learning (PBL) Untuk Meningkatkan Kemampuan

Memecahkan Masalah dan Kemampuan Berpikir Kritis Mahasiswa Semester V Tahun Akademik 2016/2017 Universitas Islam Balitar

Konstruktivisme, 10 (1): 35-48

pendidikan yang berlaku secara global. Beberapa perubahan paradigma yang dapat ditengarai adalah paradigma Sains sebagai produk berubah menjadi Sains sebagai proses, belajar berbasis pengetahuan berubah menjadi berbasis kompetensi, pembelajaran sebagai kegiatan instruktif menjadi pembelajaran sebagai kegiatan fasilitatif, serta penilaian konseptual berubah menjadi penilaian autentik (Susanto dalam Figianti, 2013).

Rendahnya mutu pendidikan ini disebabkan oleh banyak faktor. Salah satu faktor dari segi guru, adalah guru kurang kreatif dalam menyelenggarakan pendidikan dan pembelajaran di sekolah. Selama ini pembelajaran yang dilakukan masih menggunakan metode konvensional yang berpusat pada guru. Walaupun telah banyak metode pembelajaran inovatif yang berkembang dan telah terbukti dapat meningkatkan keaktifan siswa, namun seolah-olah guru enggan untuk menerapkannya karena kekhawatiran tidak terselesaikannya beban materi yang harus diajarkan. Selain itu, kurangnya pemanfaatan sumber informasi lain selain buku teks menjadi penyebab mutu pendidikan di Indonesia masih rendah bila dibandingkan dengan negara-negara lain.

Guru sebagai tenaga pengajar yang profesional harus memiliki beberapa kemampuan untuk dapat membentuk keterampilan proses dalam diri siswa. Kemampuan tersebut berupa pengaplikasian berbagai teori belajar, kemampuan memilih dan menerapkan metode mengajar yang efektif dan efisien, kemampuan melibatkan siswa untuk berpartisipasi aktif, serta kemampuan menciptakan suasana yang kondusif untuk menunjang tercapainya tujuan pembelajaran. Istilah mengajar mempunyai makna jauh lebih dalam daripada hanya menyajikan materi kepada peserta didik agar mereka bisa mengingat banyak hal. Seorang pengajar yang baik hendaknya menyediakan prosedur pembelajaran yang dapat membantu para siswa untuk memformulasikan kembali informasi baru atau mengkonstruk pengetahuan awal mereka melalui penyediaan inferensi informasi baru atau mengelaborasi informasi tersebut secara detail, dan membangkitkan hubungan antara informasi baru tersebut dengan pengetahuan awal (Dasna, 2006).

Berdasarkan hasil observasiterhadap kegiatan pembelajaran mata kuliah Strategi Belajar Mengajar (SBM)program studi Pendidikan Biologi, Universitas Islam Balitar diperoleh informasi bahwa semua mahasiswa dapat mengikuti pembelajaran di kelas karena mereka telah membuat resume kelompok terhadap materi yang dipelajari. Kegiatan pembelajaran di kelas adalah presentasi untuk materi berbagai pendekatan pembelajaran dan 
Eva Nurul Malahayati. 2018. Penerapan Model Pembelajaran Cooperative Integrated

Reading Dipadu Problembased Learning (PBL) Untuk Meningkatkan Kemampuan

Memecahkan Masalah dan Kemampuan Berpikir Kritis Mahasiswa Semester V Tahun Akademik 2016/2017 Universitas Islam Balitar

Konstruktivisme, 10 (1): 35-48

dilanjutkan dengan diskusi. Selama kegiatan diskusi berlangsung ada beberapa mahasiswa yang mengajukan pertanyaan. Menurut analisis saya, pertanyaan yang diajukan masih pada tingkat kogntif rendah. Selain itu, ada beberapa pertanyaan yang belum terselesaikan dengan baik terutama masalah-masalah yang berkaitan dengan penerapan konsep yang sedang mereka pelajari. Mereka belum menunjukkan kemampuan berpikir kritis untuk memecahkan masalah yang muncul. Pada saat presentasi mereka menggunakan media power point untuk menambah kejelasan materi yang disampaikan namun penggunaan power point hanya pada poin-poin penting tetapi belum ada gambar, tabel, atau grafik yang dapat menunjang kelancaran dan pemahaman materi yang disampaikan. Berdasarkan gejala-gejala yang nampak maka dapat disimpulkan bahwa kemampuan berpikri kritis dan kemampuan untuk memecahkan masalah harus ditingkatkan lagi.

Pemberdayaan kemampuan berpikir kritis dan memecahkan masalah sangat penting dalam kegiatan pembelajaran Pendidikan Biologi demi menciptakan lulusan sarjana pendidikan yang kelak akan menjadi guru yang profesional. Hudoyo (dalam Lestari, 2010) berpendapat bahwa memecahkan masalah merupakan aktivitas intelektual tingkat tinggi. Hal ini senada dengan teori belajar yang dikemukakan oleh Gagne (dalam Winkel, 1996). Berdasarkan teori belajar tersebut dapat diketahui bahwa ketrampilan intelektual tingkat tinggi dapat dikembangkan melalui pemecahan masalah. Memecahkan masalah merupakan tipe belajar yang paling tinggi dari tipe belajar yang dikemukakan oleh Gagne (dalam Winkel, 1996), yaitu belajar isyarat, stimulus respon, rangkaian gerak, rangkaian verbal, membedakan, pembentukan konsep, pembentukan aturan, dan pemecahan masalah. Dengan demikian, antara ketrampilan intelektual tingkat tinggi dengan kemampuan memecahkan masalah memiliki keterkaitan.

Model pembelajaran kooperatif yang dapat digunakan untuk membantu siswa dalam memecahkan masalah adalah model pembelajaran CIRC karena langkah-langkah dalam CIRC dapat mengarahkan siswa untuk memecahkan masalah. Penggunaan model CIRC akan mengajak siswa untuk berpikir tentang masalah yang berkaitan dengan materi. Siswa akan berusaha untuk memecahkan masalah tersebut dan menyampaikan hasil pemikirannya kepada siswa lain, sehingga siswa akan saling bertukar pikiran untuk memecahkan masalah tersebut. Hal ini didukung oleh Slavin (1995) dalam Figianti (2013) yang berpendapat bahwa model pembelajaran CIRC dapat meningkatkan 
Eva Nurul Malahayati. 2018. Penerapan Model Pembelajaran Cooperative Integrated

Reading Dipadu Problembased Learning (PBL) Untuk Meningkatkan Kemampuan

Memecahkan Masalah dan Kemampuan Berpikir Kritis Mahasiswa Semester V Tahun Akademik 2016/2017 Universitas Islam Balitar

Konstruktivisme, 10 (1): 35-48

kemampuan siswa dalam menyelesaikan soal pemecahan masalah dan memberikan solusi terhadap permasalahan yang diberikan oleh guru. Siswa akan berpikir kritis atau berpikir tingkat tinggi untuk memecahkan masalah yang dihadapinya sehingga kemampuan berpikir kritis akan meningkat apabila kemampuan memecahkan masalah juga meningkat.

Hasil penelitian oleh Afriani (2010) menunjukkan bahwa model pembelajaran CIRC dapat meningkatkan kemampuan siswa dalam memberikan suatu solusi terhadap suatu permaslahan yang diberikan oleh guru dan dapat meningkatkan rasa percaya diri siswa kerena mereka bisa menemukan sendiri konsep dari materi yang dipelajari dan berani menyampaikan pendapat di dalam kelas.

Model pembelajaran yang berbasis konstruktivisme adalah model pembelajaran Problem Based Learning (PBL). Pada proses pembelajaran menggunakan model PBL titik awal pembelajaran berdasarkan masalah dalam kehidupan nyata dan lalu dari masalah ini siswa dirangsang untuk mempelajari masalah ini berdasarkan pengetahuan dan pengalaman baru.PBL sangat efektif digunakan untuk mengembangkan kemampuan berpikir tingkat tinggi siswa, membantu siswa dalam memproses informasi yang dimiliki, dan membantu siswa untuk membangun pengetahuannya tentang dunia sosial dan dunia fisik yang ada di sekitarnya. PBL tidak dirancang untuk membantu guru dalam memberikan informasi sebanyak-banyaknya kepada siswa. PBL terutama dikembangkan untuk mengembangkan kemampuan berpikir, pemecahan masalah, dan ketrampilan intelektual; belajar berbagai peran orang dewasa melalui pelibatan mereka dalam pengalaman nyata atau simulasi; dan menjadi pebelajar siswa yang mandiri (Sudibyo, 2003).

Model pembelajaran CIRC yang dipadu dengan PBL diharapkan akan lebih efektif dalam meningkatkan kemampuan memecahkan masalah dan berpikir kritis karena siswa akan bekerja dalam kelompok untuk mencari alternatif pemecahan masalah atas rumusan masalah yang ditemukannya.

\section{METODE}

Penelitian ini merupakan penelitian deskriptif kualitatif.Penelitian yang dilakukan terdiri atas dua siklus. Setiap siklus dilaksanakan pada satu topik bahasan untuk mengetahui hasil yang telah dicapai oleh subjek penelitian 
Eva Nurul Malahayati. 2018. Penerapan Model Pembelajaran Cooperative Integrated

Reading Dipadu Problembased Learning (PBL) Untuk Meningkatkan Kemampuan

Memecahkan Masalah dan Kemampuan Berpikir Kritis Mahasiswa Semester V Tahun Akademik 2016/2017 Universitas Islam Balitar

Konstruktivisme, 10 (1): 35-48

sebagai dasar untuk perbaikan pada siklus selanjutnya. Setiap siklus terdiri atas 4 tahapan yaitu perencanaan, pelaksanaan tindakan, observasi dan refleksi.

Instrumen yang digunakan dalam penelitian ini bertujuan untuk memperoleh data tentang kemampuan memecahkan masalah mahasiswa, kemampuan berpikir kritis mahasiswa, respons mahasiswa, serta data pelaksanaan siklus belajar oleh dosen model.Penjelasan mengenai data, sumber data serta instrumen yang digunakan dapat dilihat dalam Tabel 1.

\section{Tabel 1 Data penelitian, Sumber Data, serta Instrumen Peneitian}

\begin{tabular}{|c|c|c|c|}
\hline No & Data & Sumber Data & Instrumen \\
\hline 1. & $\begin{array}{l}\text { Kemampuan } \\
\text { memecahkan masalah }\end{array}$ & Mahasiswa & $\begin{array}{l}\text { - Daftar Wawancara Dosen } \\
\text { - Lembar Kerja Mahasiswa } \\
\text { - Rubrik kemampuan } \\
\text { memecahkan masalah } \\
\text { - Catatan Lapangan }\end{array}$ \\
\hline 2. & $\begin{array}{l}\text { Kemampuan berpikir } \\
\text { kritis }\end{array}$ & Mahasiswa & $\begin{array}{l}\text { - Daftar Wawancara Dosen } \\
\text { - Tes tulis } \\
\text { - Rubrik kemampuan berpikir } \\
\text { kritis }\end{array}$ \\
\hline 3. & $\begin{array}{lr}\text { Respon } & \text { mahasiswa } \\
\text { Terhadap } & \text { Pembelajarn } \\
\text { CIRC dipadu PBL }\end{array}$ & Mahasiswa & - Angket balikan mahasiswa \\
\hline
\end{tabular}

Dalam penelitian ini, peneliti bertindak sebagai perancang penelitian sekaligus sebagai pelaksana tindakan.Selama kegiatan pelaksanaantindakandi kelas peneliti dibantu oleh 2 orang yang bertindak sebagai observer. Penelitian dilaksanakan di Fakultas Keguruan dan IImu Pendidikan Universitas Islam Balitar Blitar selama 1 bulan. Subjek penelitian ini adalah mahasiswa peserta mata kuliah Strategi Belajar Mengajar semester V tahun akademik 2016/2017 yang berjumlah 24 mahasiswi.

\section{HASIL}

Hasil penilaian kemampuan memecahkan masalahmahasiswa pada siklus I ditentukan dari skor yang diperoleh berdasarkan rubrik kemampuan memecahkan masalahmahasiswa siklus I. Berdasrakan data skor kemampuan memecahkan masalah mahasiswa pada siklus I dapat diketahui bahwa rata- 
Eva Nurul Malahayati. 2018. Penerapan Model Pembelajaran Cooperative Integrated

Reading Dipadu Problembased Learning (PBL) Untuk Meningkatkan Kemampuan

Memecahkan Masalah dan Kemampuan Berpikir Kritis Mahasiswa Semester V Tahun Akademik 2016/2017 Universitas Islam Balitar

Konstruktivisme, 10 (1): 35-48

rata kemampuan memecahkan masalah sebesar 69,4\%.Nilai ini diperoleh berdasarkan skoring yang dilakukan pada Lembar Kerja Mahasiswa (LKM). Dari LKM yang telah dikerjakan oleh mahasiswa terlihat bahwa kemampuan dalam merumuskan masalah masih rendah. Hal ini ditunjukkan dengan banyaknya mahasiswa yang merumuskan masalah yang tidak sesuai dengan masalah yang seharusnya dipecahkan.

Hasil kemampuanberpikir kritismahasiswa pada siklus 1 menunjukkan bahwa rata-rata kemampuanberpikir kritis mahasiswa adalah sebesar72,75\%. Kemampuanberpikir kritis dihitung berdasarkan rubrik kemampuanberpikir kritis.Kemampuan berpikir kritis juga dihitung dari hasil tes di akhir siklus II yang dinilai berdasarkan rubrik kemampuan berpikir kritis. Hasil akhir dari kedua data tersebut dapat diketahui bahwa rata-rata kemampuan berpikir kritis mahasiswa sebesar $57 \%$.

Penilaian kemampuan memecahkan masalahmahasiswa pada siklus II ditentukan berdasarkan skor yang ada pada rubrik kemampuan memecahkan masalah sehingga dapat diketahui bahwa rata-rata kemampuan memecahkan masalah adalah88,8\%. Hasil kemampuanberpikir kritismahasiswa pada siklus I menunjukkan bahwa rata-rata kemampuanberpikir kritis mahasiswa adalah sebesar93,75\%.Kemampuanberpikir kritisini dihitung berdasarkan rubrik kemampuanberpikir kritis. Selain itu, kemampuan berpikir kritis juga dihitung dari hasil tes di akhir siklus II yang dinilai berdasarkan rubrik kemampuan berpikir kritisdiketahui bahwa rata-rata kemampuan berpikir kritis mahasiswa sebesar $71 \%$.

Berdasarkan hasil analisis data yang telah dipaparkan sebelumnya maka dapat diketahui pencapaian kemampuan memecahkan masalah dan kemampuan berpikir kritis mahasiswa pada siklus II mengalami peningkatan jika dibandingkan dengan siklus I. Ringkasan peningkatan kemampuan memecahkan masalah dan kemampuan berpikir kritismahasiswa dapat dilihat pada Tabel 2 dan Tabel 3. 
Eva Nurul Malahayati. 2018. Penerapan Model Pembelajaran Cooperative Integrated

Reading Dipadu Problembased Learning (PBL) Untuk Meningkatkan Kemampuan

Memecahkan Masalah dan Kemampuan Berpikir Kritis Mahasiswa Semester V Tahun Akademik 2016/2017 Universitas Islam Balitar

Konstruktivisme, 10 (1): 35-48

Tabel 2 Perbandingan Hasil Kemampuan Memecahkan Masalah

\begin{tabular}{lc}
\hline Tindakan & $\begin{array}{c}\text { Presentase } \\
\text { Kemampuan } \\
\text { Memecahkan } \\
\text { Masalah }\end{array}$ \\
\hline Siklus I & $69,4 \%$ \\
\hline Siklus II & $88,88 \%$ \\
\hline
\end{tabular}

Tabel 4Perbandingan Hasil Kemampuan Berpikir Kritis

\begin{tabular}{lc}
\hline \multicolumn{1}{c}{ Tindakan } & $\begin{array}{c}\text { Presentase } \\
\text { Keterampilan Berpikir } \\
\text { Kritis }\end{array}$ \\
\hline Siklus I & $57 \%$ \\
\hline Siklus II & $71 \%$ \\
\hline
\end{tabular}

Berdasarkan Tabel 2 dapat dilihat bahwa peningkatan kemampuan memecahkan masalah dari siklus I ke siklus II sebesar 19,48\%. Begitupun halnya kemampuan berpikir kritismahasiswa berdasarkan LKM terjadi peningkatan sebesar29,80\% sedangkan peningkatan kemampuan berpikir kritismahasiswa berdasarkan postes sebesar $24 \%$. Peningkatan kemampuan memecahkan masalah dan kemampuan berpikir kritis dapat digambarkan dalam grafik di Gambar 1.
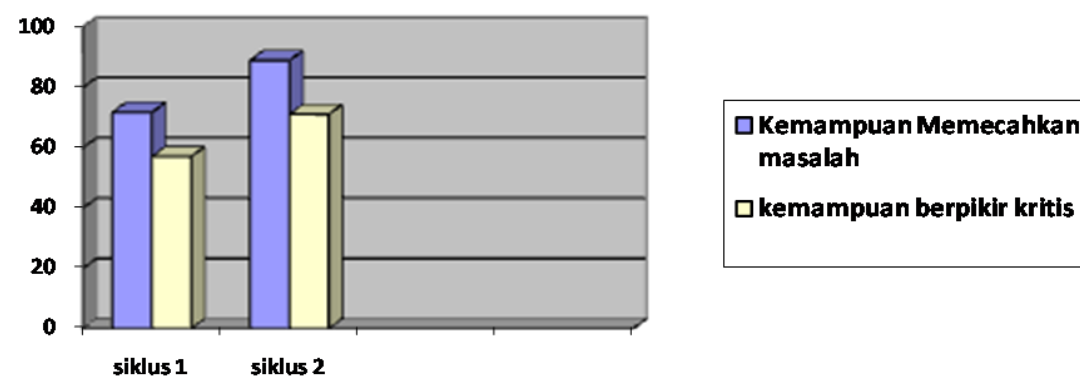

Gambar 1 Grafik Peningkatan kemampuan memecahkan masalah dan kemampuan berpikir kritis mahasiswa dari Siklus I ke Siklus II 
Eva Nurul Malahayati. 2018. Penerapan Model Pembelajaran Cooperative Integrated

Reading Dipadu Problembased Learning (PBL) Untuk Meningkatkan Kemampuan

Memecahkan Masalah dan Kemampuan Berpikir Kritis Mahasiswa Semester V Tahun Akademik 2016/2017 Universitas Islam Balitar

Konstruktivisme, 10 (1): 35-48

\section{BAHASAN}

Keterlaksanaan pembelajaran pada siklus I oleh Dosen telah mencapai $100 \%$. Pelaksanaan pembelajaran di siklus I terdapat kekurangan yaitu bacaan yang ada di LKM masih belum terarah dan belum menunjukkan fenomena terkait masalah yang diharapkan muncul untuk diselesaikan, alokasi waktu yang tidak sesuai dengan yang sudah direncanakan di RPPS, jumlah kelompok yang masih terlalu banyak sehingga tidak efisien ketika presentasi kelas, penentuan anggota kelompok yang belum terstruktur, dan teknik orientasi siswa pada masalah terlalu lama karena beberapa mahasiswa tidak memahami tekniknya. Pada siklus II hal tersebut telah mengalami perbaikan dan diminimalisir untuk terjadi kembali.

Pada siklus I dan siklus II Dosen model tetap meenggunakan pembelajaran CIRC yang dipadu dengan PBL karena model pembelajaran ini dirasa mampu meningkatkan kemampuan memecahkan masalah dan kemampuan berpikir kritis mahasiswa dimana kedua kemampuan tersebut sangat diperlukan untuk abad 21 saat ini. Pemunculan fenomena-fenomena yang ditampilkan dalam bacaan dapat memicu mahasiswa untuk merumuskan masalah dan berusaha menyelesaikannya dengan baik sehingga akan memberdayakan mereka untuk berpikir tingkat tinggi atau berpikir kritis dan memecahkan masalah yang ditemukannya.

Pelaksanaan pembelajaran yang baik itu tergantung bagaimana guru menguasai kelas, karena guru sebagai pelaksana dalam pembelajaran memegang peranan penting. Marsaja (2008) menyatakan bahwa peran utama guru dalam pembelajaran adalah: 1) motivator, dengan memberikan rangsangan agar siswa aktif dan memiliki gairah berpikir; 2) fasilitator, dengan menunjukkan jalan keluar jika ada hambatan dalam proses berpikir siswa; 3) penanya, dengan memberi pertanyaan yang membimbing menyadarkan siswa dari kekeliruan yang mereka buat dan memberi keyakinan; 4) administrator, dengan bertanggung jawab terhadap seluruh kegiatan dalam kelas; 5) pengarah, dengan memimpin arus berpikir siswa pada tujuan yang diharapkan; 6) manajer, dengan mengelola sumber belajar, waktu, dan organisasi kelas; 7) rewarder, dengan memberikan penghargaan pada prestasi yang dicapai dalam rangka peningkatan semangat dan motivasi siswa dalam belajar.

Melihat begitu besar peran guru dalam pembelajaran maka diharapkan guru mampu memilih model pembelajaran yang sesuai untuk peserta didik 
Eva Nurul Malahayati. 2018. Penerapan Model Pembelajaran Cooperative Integrated

Reading Dipadu Problembased Learning (PBL) Untuk Meningkatkan Kemampuan

Memecahkan Masalah dan Kemampuan Berpikir Kritis Mahasiswa Semester V Tahun Akademik 2016/2017 Universitas Islam Balitar

Konstruktivisme, 10 (1): 35-48

yang dapat melatih keterampilan peserta didik, dan memberikan pelajaran yang bermakna kepada peserta didik. Holil (2008) mengatakan bahwa dalam proses belajar siswa seharusnya mendapat bantuan dan bimbingan guru agar mereka lebih terarah sehingga baik proses pelaksanaan maupun tujuan pembelajaran dapat terlaksana dan tercapai dengan baik. Dengan begitu guru harus mampu memberikan fasilitas yang baik kepada peserta didik agar peserta didik juga mampu belajar dengan baik.

\section{Kemampuan Memecahkan Masalah}

Paparan dan analisis data siklus I menunjukkan bahwa kemampuan memecahkan masalah mahasiswa yang mampu dicapai sebesar $69,4 \%$ dan pada siklus II sebesar $88,88 \%$ sehingga dapat diketahui bahwa nilai kemampuan memecahkan masalah mahasiswa selama mengikuti pembelajaran CIRC dipadu dengan PBL mengalami peningkatan sebesar $19,48 \%$.

Berdasarkan paparan dan analisis data penelitian ini menunjukkan bahwa pembelajaran CIRC dipadu dengan PBL dapat meningkatkan kemampuan memecahkan masalah mahasiswa semester $\mathrm{V}$ tahun akademik 2016/ 2017 pada matakuliah SBM. Hal ini sesuai dengan teori yang menyatakan bahwa model pembelajaran CIRC dapat meningkatkan kemampuan memecahkan masalah karena bacaan yang diberikan mengandung fenomena yang dapat membantu mahasiswa dalam merumuskan dan memecahkan masalah.Muhibin (2006) dalam Figianti (2013) mengemukakan bahwa kemampuan memecahkan masalah pada dasarnya adalah belajar menggunakan metode-metode ilmiah atau berpikir secara sistematis ,logis, teratur, dan teliti. Tujuannya adalah untuk memperoleh kemampuan dan kecakapan kognitif untuk memecahkan masalah secara rasional, lugas dan tuntas. Jadi, siswa yang belajar memecahkan masalah akan dapat membangun pemikirannya untuk mencari solusi dari permasalahan yang ada.

Model pembelajaran kooperatif yang dapat digunakan untuk membantu siswa dalam memecahkan masalah adalah model pembelajaran CIRC karena langkah-langkah dalam CIRC dapat mengarahkan siswa untuk memecahkan masalah. Penggunaan model CIRC akan mengajak siswa untuk berfikir tentang masalah yang berkaitan dengan materi. Siswa akan berusaha untuk 
Eva Nurul Malahayati. 2018. Penerapan Model Pembelajaran Cooperative Integrated

Reading Dipadu Problembased Learning (PBL) Untuk Meningkatkan Kemampuan

Memecahkan Masalah dan Kemampuan Berpikir Kritis Mahasiswa Semester V Tahun Akademik 2016/2017 Universitas Islam Balitar

Konstruktivisme, 10 (1): 35-48

memecahkan masalah tersebut dan menyampaikan hasil pemikirannya kepada siswa lain, sehingga siswa akan saling bertukar pikiran untuk memecahkan masalah tersebut. Hal ini didukung oleh Slavin (1995) dalam Figianti (2013) yang berpendapat bahwa model pembelajaran CIRC dapat meningkatkan kemampuan siswa dalam menyelesaikan soal pemecahan masalah dan memberikan solusi terhadap permasalahan yang diberikan oleh guru. Siswa akan berpikir kritis atau berpikir tingkat tinggi untuk memecahkan masalah yang dihadapinya sehingga kemampuan berpikir kritis akan meningkat apabila kemampuan memecahkan masalah juga meningkat.

Model PBL dirasa sangat efektif untuk digunakan dalam mengembangkan kemampuan berpikir tingkat tinggi siswa, membantu siswa dalam memproses informasi yang dimiliki, dan membantu siswa untuk membangun pengetahuannya tentang dunia sosial dan dunia fisik yang ada di sekitarnya. PBL tidak dirancang untuk membantu guru dalam memberikan informasi sebanyak-banyaknya kepada siswa. PBL terutama dikembangkan untuk mengembangkan kemampuan berfikir, pemecahan masalah, dan ketrampilan intelektual; belajar berbagai peran orang dewasa melalui pelibatan mereka dalam pengalaman nyata atau simulasi; dan menjadi pebelajar siswa yang mandiri (Sudibyo, 2003).

\section{Kemampuan Berpikir Kritis}

Berdasarkan paparan dan analisis data penelitian ini menunjukkan bahwa kemampuan berpikir kritis mahasiswa yang dilihat dari proses pembelajaran yaitu Lembar kerja Mahasiswa (LKM) pada siklus I sebesar 72,22 $\%$ dan pada siklus II sebesar 93,75\% sehingga dapat diketahui bahwa kemampuan berpikir kritis mahasiswa mengalami peningkatan sebesar 29,80\% dari siklus I ke siklus II. Selain itu, kemampuan berpikir kritis juga dilihat dari nilai postes pada akhir tiap siklus. Nilai postes mahasiswa pada siklus I sebesar $57 \%$ dan pada siklus II sebesar $71 \%$ maka dapat diketahui bahwa kemampuan berpikir kritis mahasiswa mengalami peningkatan sebesar $24 \%$ dari siklus I ke siklus II.

Lilisari (2000) dan Krulik dan Rudnick (1999) dalam Muhfahroyin (2009) menyatakan bahwakemampuan berpikir kritis merupakan aktivitas berpikir tingkat tinggi. Perencanaan pembelajaran IPA oleh guru untuk pengembangan kemampuan berpikir kritis siswa adalah keharusan (Schaferman (1999) dalam 
Eva Nurul Malahayati. 2018. Penerapan Model Pembelajaran Cooperative Integrated

Reading Dipadu Problembased Learning (PBL) Untuk Meningkatkan Kemampuan

Memecahkan Masalah dan Kemampuan Berpikir Kritis Mahasiswa Semester V Tahun Akademik 2016/2017 Universitas Islam Balitar

Konstruktivisme, 10 (1): 35-48

Muhfahroyin (2009)). Hal ini didukung oleh pernyataan Presseisen (1985) bahwa agar siswa memiliki ketrampilan intelektual tingkat tinggi harus dilatih keterampilan kritis, kreatif, pemecahan masalah dan membuat keputusan.Berpikir kritis ini mengaktifkan kemampuan melakukan analisis dan evaluasi bukti, identifikasi pertanyaan, kesimpulan logis, memahami implikasi argumen (Friedrichsen, 2001, dalam Muhfahroyin, 2009).

Model pembelajaran CIRC merupakan salah satu model pembelajaran kooperatif yang lebih memanfaatkan kerja sama dalam kelompok untuk membantu siswa belajar memahami materi pembelajaran melalui bacaan/ wacana/ kliping dengan cara membaca, menganalisis, memecahkan masalah, menyelesaikan tugas dari guru, menulis/ menyusun laporan hasil kerja kelompok, dan presentasi hasil kerja kelompok. Model pembelajaran CIRC memiliki beberapa kelebihan. Hasil penelitian oleh Afriani (2010) menunjukkan bahwa model pembelajaran CIRC dapat meningkatkan kemampuan siswa dalam memberikan suatu solusi terhadap suatu permasalahan yang diberikan oleh guru dan dapat meningkatkan rasa percaya diri siswa kerena mereka bisa menemukan sendiri konsep dari materi yang dipelajari dan berani menyampaikan pendapat di dalam kelas. Kemampuan dalam memberikan solusi terhadap suatu permasalahan yang diberikan merupakan salah satu aspek atau indikator dari berpikir kritis. Lebih lanjut, pembelajaran berdasarkan masalah telah dikenal sejak zaman John Dewey. Pembelajaran berbasis masalah digunakan untuk merangsang berfikir tingkat tinggi dalam situasi berorientasi masalah, termasuk didalamnya belajar bagaimana belajar. Peran guru dalam pembelajaran berbasis masalah adalah menyajikan masalah, mengajukan pertanyaan, dan memfasilitasi penyelidikan dan dialog.

Berdasarkan paparan dan analisis data penelitian ini menunjukkan bahwa pembelajaran CIRC dipadu dengan PBL dapat meningkatkan kemampuan berpikir kritis mahasiswa semester V tahun akademik 2016/ 2017 pada matakuliah SBM. Hal ini telah sesuai dengan teori bahwa pembelajaran CIRC dipadu PBL dapat meningkatkan kemampuan berpikir kritis.

\section{SIMPULAN DAN SARAN}

Berdasarkan analisis data dan pembahasan yang telah dilaksanakan pada penelitian ini maka dapat ditarik kesimpulan sebagai berikut.

1. Penerapan pembelajaran CIRC dipadu dengan PBLdapat meningkatkan kemampuan memecahkan masalahmahasiswa semester $\mathrm{V}$ tahun 
Eva Nurul Malahayati. 2018. Penerapan Model Pembelajaran Cooperative Integrated

Reading Dipadu Problembased Learning (PBL) Untuk Meningkatkan Kemampuan

Memecahkan Masalah dan Kemampuan Berpikir Kritis Mahasiswa Semester V Tahun Akademik 2016/2017 Universitas Islam Balitar

Konstruktivisme, 10 (1): 35-48

akademik 2016/ 2017 Matakuliah SBM Universitas Islam Balitar, hal ini didasarkan pada meningkatnya nilai rata-rata prosentasekemampuan memecahkan masalah pada siklus I dan siklus II berturut-turut $69,4 \%$ dan $88,88 \%$, sehingga terjadi peningkatan sebesar $19,48 \%$ dari siklus I ke siklus II.

2. Penerapan pembelajaran CIRC dipadu dengan PBLdapat meningkatkan kemampuan berpikir kritismahasiswa semester V tahun akademik 2016/ 2017 Matakuliah SBM Universitas Islam Balitar,hal ini didasarkan pada meningkatnya nilai rata-rata prosentasekemampuan berpikir kritis berdasarkan LKM pada siklus I dan siklus II berturut-turut $72,22 \%$ dan $93,75 \%$, sehingga dapat dikatakan terjadi peningkatan sebesar29,80\% dibanding dengan perolehan rata-rata kemampuan berpikir kritis pada siklus I, sedangkan kemampuan berpikir kritis berdasarkan nilai postes pada siklus I dan siklus II berturut-turut $57 \%$ dan $71 \%$, sehingga dapat dikatakan terjadi peningkatan sebesar24\% dari siklus I ke siklus II.

Berdasarkan hasil penelitian yang telah dilaksanakan, maka peneliti dapat menyarankan beberapa hal sebagai berikut.

1. Hasil dari penerapan pembelajaran CIRC dipadu dengan PBLterbukti telah berhasil meningkatkan kemampuan memecahkan masalah dan kemampuan berpikir kritis, oleh karena itu bagi Dosen Pembina matakuliah disarankan untuk menerapkan model pembelajaran ini pada materi dengan karakteristik yang sesuai.

2. Seluruh aspek penilaian harus diinformasikan kepada mahasiswa di awal perkuliahan agar mahasiswa mengetahui dan berusaha untuk selalu menempatkan dirinya pada kemampuan yang sesuai.

\section{DAFTAR RUJUKAN}

Afriani, Dini. 2010. Pengaruh penerapan model pembelajaran CIRC terhadap hasil belajar IPS geografi Siswa kelas VIII SMPN 8 Malang tahun pelajaran 2010/2011. Skripsi tidak diterbitkan. Malang: UM.

Dasna, I Wayan. 2005. Model-model Pembelajaran Konstruktivistik dalam Pengajaran Sains/ Kimia. Universitas Negeri Malang: FMIPA Jurusan Kimia. 
Eva Nurul Malahayati. 2018. Penerapan Model Pembelajaran Cooperative Integrated

Reading Dipadu Problembased Learning (PBL) Untuk Meningkatkan Kemampuan

Memecahkan Masalah dan Kemampuan Berpikir Kritis Mahasiswa Semester V Tahun Akademik 2016/2017 Universitas Islam Balitar

Konstruktivisme, 10 (1): 35-48

Figianti, Arista Dini. 2013. Pengaruh Model Pembelajaran Cooperative Integrated Reading and Composition (CIRC) terhadap Kemampuan memecahkan Masalah pada Mata pelajaran Geografi di SMA Taman Siswa Malang. Skripsi tidak diterbitkan. Malang: Universitas negeri Malang.

Holil, Anwar. 2008. Menjadi Manusia Pembelajar, (Online)

(http://anwarholil.blogspot.com/ 2010/05/permudah-pemahaman-konseppembelajaran.html, diakses 22 Oktober 2017).

Marsaja. 2008. Mendidik dengan Strategi Inkuiri, (Online) (http://marsaja.wordpress.com/2009/05/25/mendidik-dengan-strategiinkuiri, diakses 22 Oktober 2017).

Muhfahroyin. 2009. Pengaruh Strategi Pembelajaran Integrasi STAD dan TPS dan Kemampuan Akademik terhadap Hasil Belajar Kognitif Biologi, Kemampuan Berpikir Kritis, dan Keterampilan Proses Siswa SMA di Kota Metro. Disertasi tidak diterbitkan. Malang: Program Pascasarjana Universitas Negeri Malang. 